\title{
Long Acting Myeloid Growth Factor
}

National Cancer Institute

\section{Source}

National Cancer Institute. Long Acting Myeloid Growth Factor. NCI Thesaurus. Code C102862.

Any of the synthetic, long-acting hematopoietic growth factors that stimulate the growth of myeloid cells. 